\title{
NOTE
}

\section{An ancient eelgrass clone in the Baltic}

\author{
Thorsten B. H. Reusch ${ }^{1, *}$, Christoffer Boström ${ }^{2}$, Wytze T. Stam ${ }^{1}$, Jeanine L. Olsen ${ }^{1}$ \\ 'Department of Marine Biology, University of Groningen, PO Box 14, 9750 AA Haren, The Netherlands \\ ${ }^{2}$ Husö Biological Station, Åbo Akademi University, FIN-22220 Emkarby, Åland Islands, Finland
}

\begin{abstract}
We report that an eelgrass bed Zostera marina L. at the Alland Islands, northern Baltic Sea, is dominated by a single genotype which extends over an area of approximately $160 \times 40 \mathrm{~m}$. In total 47 individuals were sampled and genotyped for 6 highly polymorphic microsatellite loci. Forty-four of the ramets revealed the same 6-locus genotype, including 3 identical heterozygous loci. They were thus assigned to the same genet $(=$ clone $)$. To our knowledge, it represents the largest marine plant identified thus far. Based on estimates of horizontal rhizome growth rates, this clone may be more than $1000 \mathrm{yr}$ old. The remarkable phenotypic plasiticity of a single genotype which dominates this site illustrates that there is no simple one-to-one relationship between genetic diversity and population persistence in changing and stressful environments.
\end{abstract}

KEY WORDS: Baltic Sea C Clonal reproduction - Eelgrass Genet - Microsatellites · Ramet - Zostera marina

Seagrass meadows comprise a major component of many coastal environments throughout the world (den Hartog 1970). Most of the approximately 60 seagrass species reproduce both sexually through seeds and vegetatively by rhizome branching and the formation of new leaf shoots. Any individual emerging from a seed (a genet or clone sensu Harper 1977) may thus give rise to secondary shoots, or ramets. Because in many seagrass species rhizome connections break after a few years, the identification of ramets and genets is only possible using genetic markers. An assessment of the contribution of clonal growth within seagrass beds is essential for subsequent analysis of inbreeding, or population differentiation, as large amounts of clonal growth will bias the outcome of such studies.

\footnotetext{
-Present address: Max-Planck-Institut für Limnologie, AugustThienemann-Str. 2, D-24306 Plön, Germany

E-mail: reusch@mpil-ploen.mpg.de
}

Information on clonal diversity in seagrass populations has been hampered in the past by low variability of traditional genetic markers such as allozymes (De Heij \& Nienhuis 1992, Capiomont et al. 1996, Waycott et al. 1996, Schlueter \& Guttman 1998). Recent reports using DNA-based genetic markers suggest that the clonal structure in seagrass beds varies within and among species. Among the largest clones identified are those in Posidonia australis which are $16 \mathrm{~m}$ in diameter (Waycott 1995). In 6 Mediterranean populations of Posidonia oceanica, data presented by Procaccini \& Mazella (1998) allow an estimate of the maximal genet sizes encountered based on microsatellite polymorphism. They found identical multi-locus genotypes in 3 to 4 neighbouring plants sampled at $7 \mathrm{~m}$ intervals, suggesting a maximal clone size of approximately $30 \mathrm{~m}$. In a western Baltic population, Reusch et al. (1999b) found that genets of eelgrass Zostera marina attained a diameter of $17 \mathrm{~m}$, corresponding to an estimated age of $67 \mathrm{yr}$, using the 7 -locus microsatellite genotype of 80 mapped ramets.

Material and methods. The subtidal eelgrass Zostera marina $\mathrm{L}$. bed is situated in the northern Baltic Sea (Fig. 1). Using SCUBA, 18 leaf shoots were sampled randomly at Hinderbengtsviken, Åland Islands, central Baltic Sea in a midbed area of 20 (perpendicular to shore) $\times 40 \mathrm{~m}$ (parallel to shore) at a depth ranging from 2.5 to $3.5 \mathrm{~m}$ (September 1998). The minimal distance between samples was $1 \mathrm{~m}$. Another 29 plants were collected 1 mo later at $5 \mathrm{~m}$ intervals along a transect line, $160 \mathrm{~m}$ in length, spanning the upper to lower distributional limit of the meadow (1.2 to $4.5 \mathrm{~m}$ depth). Note that 5 positions along the transect were not sampled because they fell on bare substratum.

To assign ramets to genets we used microsatellite loci, the most polymorphic genomic markers present to date (Jarne \& Lagoda 1996). Samples were genotyped for 6 loci (Zosmar CT-3 and GA-2 to GA-6, Genbank 


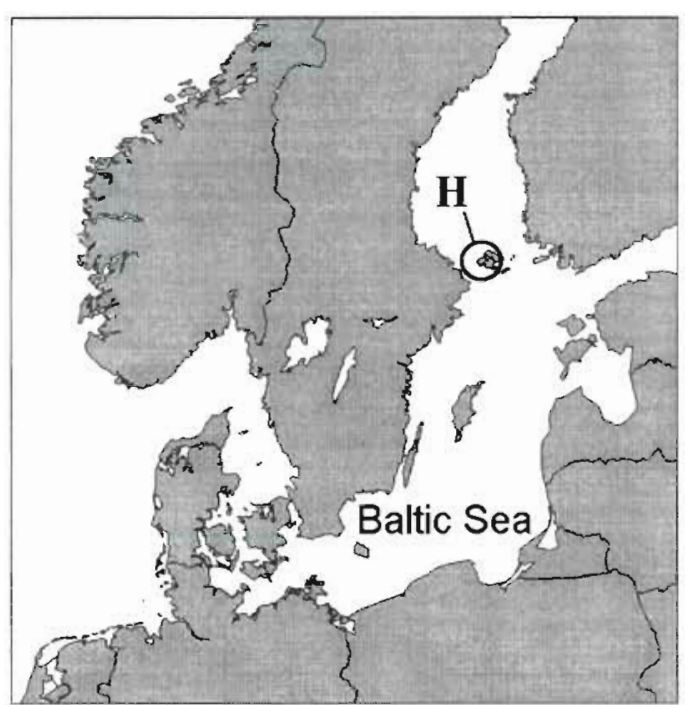

Fig. 1. Study site at Hinderbengtsviken (H), Alland Islands, central Baltic Sea (position $60^{\circ} 10^{\prime} \mathrm{N}, 20^{\circ} 32^{\prime} \mathrm{E}$ ). The site is exposed to south-westerly winds, has a sandy substratum and salinities fluctuate between 6 and $7 \%$. Annual temperatures range from 0 to $20^{\circ} \mathrm{C}$

accession-nos. AJ009898-9904, Reusch et al. 1999a). The 6 chosen loci represent 67 alleles, are not linked and follow Hardy-Weinberg-equilibrium in 8 other Baltic and North Sea populations (Reusch et al. 1999b, Reusch unpubl. data).

Plant collection, DNA-extraction, and PCR-amplification followed the method outlined in Reusch et al. (1999a) with the only modification that we used fluorescent end-labelling of forward primers instead of radioactive labelling. The $P C R$-products were then visualised on an ABI-377 automated sequencer (PerkinElmer, Fig. 2). Positive (clone) and negative controls (no template) were always included. An internal lane size standard was used for determination of allele size (Fig. 2).

Results and discussion. A single genotype was found to dominate (Table 1). All 18 mid-bed samples and 26 of the 29 plants along the $160 \mathrm{~m}$ transect belonged to the genotype ' $A$ '. Along the transect, only 3 ramets collected at intermediate positions displayed 2 additional genotypes (' $\mathrm{B}$ ' and ' $\mathrm{C}$ '), differing by 1 and 4

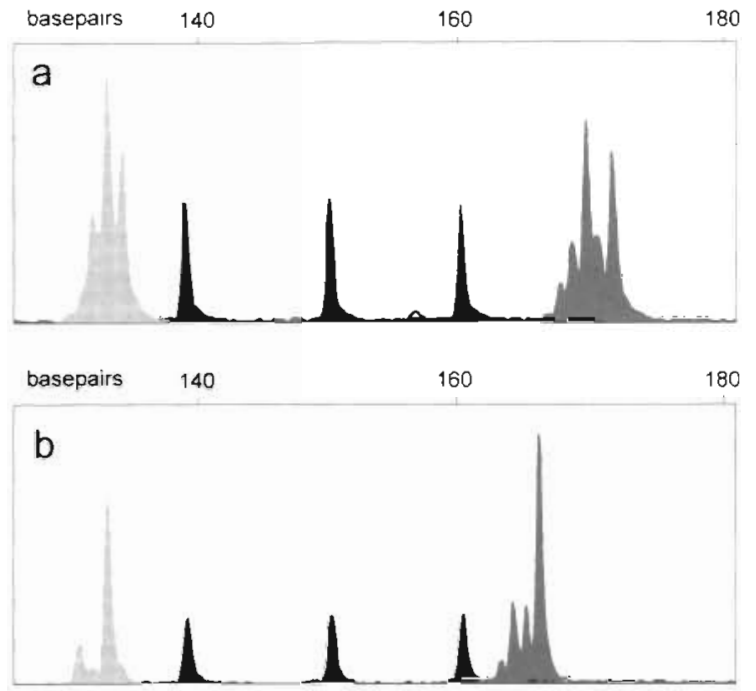

Fig. 2. Example of microsatellite genotyping of Zostera marina using the products of a fluorescently labelled duplexPCR visualized on an ABI 377 automated sequencer (PerkinElmer). The $x$-axis gives the fragment size in base pairs (bp); $y$-axis is the fluorescent signal in arbitrary units. (a) Heterozygous genotype of the dominant clone 'A' at Alland Islands for the loci Zosmar GA-2 (dark gray) and GA-3 (light gray). Allele sizes are $169 / 171 \mathrm{bp}$ and $133 / 134 \mathrm{bp}$, respectively. (b) For comparison, a double homozygous genotype from Falkenstein, a different western Baltic population (Reusch et al. 1999 b). Black peaks are size markers at 139, 150 and $160 \mathrm{bp}$

alleles, respectively, from the dominant genotype ' $A$ ' (Table 1). The similarity among the 3 genotypes identified suggests that they are sibs, or half sibs. The dominant genotype was heterozygous at 3 of the 6 loci examined (example for 2 loci in Fig. 2). It is therefore not possible that episodical sexual reproduction of flowers within this genet is responsible for a lateral expansion because any recombination would lead to segregation into both homozygous and the heterozygous genotype at each of the 3 loci according to Mendel's fundamental law of genetics (Mendel 1866). Accordingly, the probability that 44 identical heterozygous genotypes originated from sexual reproduction is infinitesimal small. Using an exact test (Raymond \& Rousset 1995) we calculated the likelihood that the observed triple heterozygous excess resulted from recombination as $2 \times 10^{-18}$.

Table 1. Microsatellite genotypes of 47 eelgrass Zostera marina samples at Aland Islands, central Baltic Sea. Allele sizes are in base pairs

\begin{tabular}{|lccccccc|}
\hline Genotype & Frequency & CT-3 & GA-2 & Microsatelite locus Zosmar & GA-3 & GA-4 & GA-6 \\
\hline A & & & $118 / 118$ & $169 / 171$ & $1.33 / 134$ & $170 / 170$ & $156 / 156$ \\
B & 44 & $118 / 118$ & $169 / 171$ & $131 / 133$ & $170 / 170$ & $156 / 156$ & $108 / 112$ \\
C & 1 & $106 / 116$ & $169 / 169$ & $133 / 133$ & $170 / 170$ & $156 / 156$ & $108 / 112$ \\
\hline
\end{tabular}


Based on 48 replicate frame samples of $25 \times 25 \mathrm{~cm}$ placed haphazardly inside the meadow, we extrapolated the shoot density and biomass of the dominant genet. Extending over an area of approximately $160 \times$ $40 \mathrm{~m}=6400 \mathrm{~m}^{2}$, it comprises some $2 \times 10^{6}$ shoots and weighs about $7000 \mathrm{~kg}$ (above and below ground fresh mass), making it the largest genet of any marine plant so far identified. Because the meadow measures approximately $200 \mathrm{~m}$ parallel to the shore, the actual clone size may be even larger. Assuming a mean horizontal spread of the meadow edge of $10 \mathrm{~cm} \mathrm{yr}^{-1}$ (Reusch et al. 1994) we estimate the age of this genet to be between 800 and $1600 \mathrm{yr}$, depending on the changing directionality of the meadow edge. Among marine benthic plants, only the brown seaweed Ascophyllum nodosum may reach similar life spans with a projected age of hundreds of years (Åberg 1992).

Previous studies have also reported genetic uniformity in Zostera marina and other seagrass species at the population level, sometimes over scales of hundreds of kilometres (Z. marina: De Heij \& Nienhuis 1992; Posidonia oceanica: Capiomont et al. 1996; Amphibolis antarctica: Waycott et al. 1996; Thalassia testudinum: Schlueter \& Guttman 1998). While such uniformity does not preclude that clones are of a very large size, above data represent no conclusive evidence that clones are, in fact, of such extended sizes. In particular when using allozymes it is likely that genets are in reality much smaller because the genetic markers used are not variable enough at the population level. DNA-based genetic markers such as RAPD (random amplified polymorphic DNA) and RFLP (restriction fragment length polymorphism) are more variable and are well suited for excluding genetic identity, i.e. for demonstrating that genotypes are different. However, when the research goal is to assess the maximal genet size and thus clonal identity, they have the disadvantage that they are dominantly/recessively inherited. Hence, it is impossible to decide whether identical genotypes belong to the same genetic individual, or whether the studied population is fixed for the chosen RAPD-primer or restriction sites on the DNA. To conclusively demonstrate that given identical genotypes arose from clonal spread, one needs to detect genetic variation at the level of the individual (i.e. heterozygosity) using a genetic marker which is inherited in a codominant fashion, such as microsatellites. Since heterozygosity would give rise to different genotypes within the population under sexual reproduction, data of this type are not prone to false conclusion of genetic identity.

The local predominance of a single clone may be due to limited sexual recruitment or to clonal competition acting over long time intervals (Eriksson 1993). The available information on sexual reproduction in the Aland archipelago suggests that flowering or fruit bearing plants are rare (Boström 1995). Accordingly, during 3 yr at our study site, flowering plants comprised only a very small fraction of the total population (C. Boström unpubl. data). While it is clear that sexual reproduction is presently limited, it will never be known whether there were more genotypes during the initial colonisation of the site

Seagrass meadows recycle nutrients, protect the substratum against erosion and serve as nursery grounds for many commercially important species. Worldwide declines of seagrass beds is of great concern to policy makers because of their vital contribution to ecosystem services (Short \& Wyllie-Escheverria 1996, Costanza et al. 1997). The persistence of plant populations in the face of changing environments has been attributed to their genotypic and genetic diversity (Montalvo et al. 1997). Where genetic diversity is dimished or lost, the population is hypothesised to be more vulnerable to extinction (Ellstrand \& Elam 1993). The fact that our ancient Baltic clone lacks measurable genetic diversity presents us with an apparent paradox: long-term ecological persistence under extreme and fluctuating environmental conditions. The Baltic is only $4000 \mathrm{yr}$ old with its present-day salinity and has undergone drastic alterations in ice cover, salinity and temperature in the past millenium - the estimated lifetime of the dominant clone. Moreover, the Hinderbengtsviken site has experienced isostatic land lift of 3 to $5 \mathrm{~m}$ in the same period (Winterhalter et al. 1981). Given the present slope of the shore at the site, this translates to a net displacement of the clone by $50 \mathrm{~m}$ seawards during the past $1000 \mathrm{yr}$ in order to compensate for the relative drop in sea level. Finally, the dominant clone grows in a water depth from 1.2 to $4.5 \mathrm{~m}$ with concomittant effects on light, sedimentation, wind exposure and ice scour. That there is no clonal niche differentiation (e.g. Silander 1979) despite such a strong environmental gradient is unexpected.

The remarkable plasiticty of a single genotype which dominates this meadow is a cautionary tale for judging the importance of genetic diversity. There may be no simple one-to-one relationship between genetic diversity and population survival in changing and stressful environments. Theoretical models of long-term population dynamics even predict that towards the extreme edges of the distributional range of a species, clonally growing individuals may outcompete those investing more into sexual reproduction (Peck et al. 1998). It would be interesting to test these models in seagrasses.

Acknowledgements. This project was funded through the European Union (contract No. ERBFMBICT961789). C.B. was financially supported by the Academy of Finland, projectnumber 38021. M. Tallqvist, K. Aarnio and C. Roos helped with the sampling. Four anonymous reviewers improved the clarity of the manuscript. 


\section{LITERATURE CITED}

Aberg P (1992) A demographic study of two populations of the seaweed Ascophyllum nodosum. Ecology 73:1473-1487

Boström C (1995) Flowering and fruit-bearing Zostera marina in Åland, northern Baltic Sea. Memoranda Soc Fauna Flora Fenn 71:7-9

Capiomont A, Sandmeier M, Caye G, Meinesz A (1996) Enzyme polymorphism in Posidonia oceanica, a seagrass endemic to the Mediterranean. Aquat Bot 54:265-277

Costanza $R$, d'Arge $R$, de Groot $R$, Farber $S$, Grasso $M$, Hannon B, Limburg K, Naeem S, O'Neill RV, Paruelo J, Raskin RG, Sutton P, van den Belt $M$ (1997) The value of the world's ecosystem services and natural capital. Nature $387: 253-260$

De Heij $H$, Nienhuis PH (1992) Intraspecific variation in isozyme patterns of phenotypically separated popuulations of Zostera marina L. in the south-western Netherlands. J Exp Mar Biol Ecol 161:1-14

den Hartog C (1970) The seagrasses of the world. Verh K Ned Akad Wet Afd Natuurkd Reeks II 59:1-275

Ellstrand NC, Elam D (1993) Population consequences of small population size: implications for plant conservation. Annu Rev Ecol Syst 24:217-242

Eriksson O (1993) Dynamics of genets in clonal plants. Trends Evol Ecol 8:313-316

Harper JL (1977) Population biology of plants. Academic Press, New York

Jarne P, Lagoda PJL (1996) Microsatellites: from molecules to populations and back. Trends Evol Ecol 11:424-429

Mendel G (1866) Versuche über Pflanzenhybriden. Verh Naturforsch Ver Brünn 4:3-17

Montalvo AM, Williams SL, Rice KJ, Buchmann SL, Cory C, Handel. SN, Nabhan GP, Primack R, Robichaux RH (1997) Restoration biology: a population biology perspective. Restor Ecol 5:277-290

Editorial responsibility: Otto Kinne (Editor),

Oldendorf/Luhe, Germany
Peck JR, Yearsley JM, Waxman D (1998) Explaining the geographic distributions of sexual and asexual populations. Nature 391:889-892

Procaccini G, Mazella L (1998) Population genetic structure and gene flow in the seagrass Posidonia oceanica assessed using microsatellite analysis. Mar Ecol Prog Ser 169:133-141

Raymond M, Rousset F (1995) Genepop (v. 1.2): population genetics software for exact tests and ecumenicism. J Hered 86:248-249

Reusch TBH, Chapman A.RO, Gröger JP (1994) Blue mussels Mytilus edulis do not interfere with eelgrass Zostera marina but fertilize shoot growth through biodeposition Mar Ecol Prog Ser 108:265-282

Reusch TBH, Stam WT, Olsen JL (1999a) Microsatellite loci in eelgrass Zostera marina reveal marked polymorphism within and among populations. Mol Ecol 8:317-322

Reusch TBH, Stam WT, Olsen JL (1999b) Size and estimated age of genets in eelgrass Zostera marina L assessed with microsatellite markers. Mar Biol 133:519-525

Schlueter MA, Guttman SI (1998) Gene flow and genetic diversity of turtle grass. Thalassia testudinum, banks ex König, in lower Florida keys. Aquat Bot 61:147-164

Short FT, Wyllie-Escheverria S (1996) Natural and humaninduced disturbance of seagrasses. Environ Conserv 25 $17-27$

Silander JA (1979) Microevolution and clone structure in Spartina patens. Science 203:658-660

Waycott M (1995) Assessment of genetic variation and clonality in the seagrass Posidonia australis using RAPD and allozyme analysis. Mar Ecol Prog Ser 116:289-295

Waycott M, Walker DI, James SH (1996) Genetic uniformity in Amphibolis antarctica, a dioecious seagrass. Heredity 76 $578-585$

Winterhaiter $B$, Flodén $T$, Ignatius $H$, Axberg $S$, Niemistö $L$ (1981) Geology of the Baltic Sea. In: Voipio A (eds) The Baltic Sea. Elsevier, Amsterdam, p 1-122

Submitted: February 26, 1999; Accepted: May 28, 1999

Proofs received from author(s): June 25, 1999 